\title{
KANDUNGAN ESCHERICHIA COLY PADA SUMBER AIR PDAM, DEPOT AIR MINUM DAN SUMUR GALI
}

\author{
Syaiful Hakim, Heru Listiono, Leni Novianti \\ Program Studi S1 Kesehatan Masyarakat, Universitas Kader Bangsa Palembang \\ J1.HM.Ryacudu No 887 Ulu Palembang Telp (0711) 510173 \\ Email : syafulhakim15@gmail.com
}

\begin{abstract}
Abstrak
Air merupakan sumber daya alam yang sangat penting dalam kehidupan baik tumbuhan, hewan maupun manusia. Menurut PERMENKES No. 492 tahun 2010 parameter mikrobiologi air minum yang wajib dipenuhi adalah batas minimum kandungan bakteri coliform dan Escherichia coly sebanyak 0 per 100 ml. Kelurahan Tanjung Raja Kecamatan Tanjung Raja Kabupaten Ogan Ilir adalah salah satu dari delapan Desa/Kelurahan yang ada di wilayah kerja Puskesmas Tanjung Raja Kecamatan Tanjung Raja yang Jumlah Penduduknya paling banyak dibandingkan dengan Desa/Kalurahan yang lain. Mobilitas masyarakat yang tinggi karena daerah perkotaan dengan penduduk padat dan berdekatan dengan pasar, tapi masih kental juga dengan penduduk asli dengan kebudayaannya, sehingga untuk pemenuhan kebutauhan air sehari hari sangat bervariasi sekali. Angka kejadian diare di Kelurahan Tanjung Raja 3 tahun terakhir untuk tahun 2016 sebanyak 85 orang, tahun 2017103 orang dan tahun 201898 orang. Tujuan penelitian ini adalah untuk mengetahui apakah ada beda rata-rata kandunagan bakteri Escherichia coly pada sumber air minum PDAM, Depot Air Minum, dan Sumur Gali. Jenis penelitian yang dilakukan adalah penelitian analitik komparatif numerik, karena pada penelitia ini akan menghubungkan beberapa variabel kategorik terhadap satu variable numerik. Dari hasil penelitian diperoleh nilai p value hasil penelitian yaitu 0,036 $\leq$ Alpha $(\alpha)$ 0,05. Dapat disimpulkan bahwa rata-rata kandungan bakteri Eschericia Coly pada ke tiga sumber air minum tersebut berbeda secara signifikan.

Kata kunci : PDAM, Depot Ait Minum, Sumur Gali
\end{abstract}

\begin{abstract}
Water is a very important natural resource in the life of plants, animals and humans. According to PERMENKES No. 492 of 2010 the microbiological parameters of drinking water that must be met are the minimum limit of the content of coliform bacteria and Escherichia coly as much as 0 per $100 \mathrm{ml}$. Tanjung Raja Sub-District, Tanjung Raja Sub-District, Ogan Ilir District, is one of eight villages in the working area of the Tanjung Raja Community Health Center in the District of Tanjung Raja, which has the most population compared to other villages / sub-districts. High community mobility due to urban areas with dense population and proximity to markets, but still thick with indigenous people with their culture, so that to meet the needs of daily water varies greatly. The incidence of diarrhea in Tanjung Raja Village in the last 3 years for 2016 was 85 people, in 2017103 people and in 201898 people. The purpose of this study was to determine whether there is a difference in the average Escherichia coly bacterial in drinking water sources of PDAMs, Drinking Water Depots, and Dug Wells. This type of research is a numerical comparative analytic study, because this research will link several categorical variables to one numerical variable. From the research results obtained $p$ value of the results of the study is $0.036 \leq$ Alpha $(\alpha) 0.05$. It can be concluded that the average content of Escherichia Coly bacteria in the three drinking water sources is significantly different.
\end{abstract}

Keywords : PDAM, Ait Drinking Depot, Dug Well 


\section{PENDAHULUAN}

Air merupakan sumber daya alam yang sangat penting dalam kehidupan baik tumbuhan, hewan maupun manusia. Air memiliki fungsi yang beragam seperti untuk memasak, mencuci, mandi dan sebagainya. Kehidupan manusia tidak terlepas dari kebutuhan akan air bersih terutama air minum. Sumber pemenuhan kebutuhan air minum berbagai macam diantaranya berasal dari air tanah, sungai, air pegunungan dan air laut. Air bersih secara umum yaitu air yang tidak berwarna, berbau dan tidak memiliki rasa. Pemenuhan kebutuhan air minum yang bersih oleh masyarakat di kota besar semakin meningkat, sehingga produk air minum dalam kemasan banyak dikonsumsi. Akan tetapi air minum dalam kemasan cukup mahal, sehingga muncul produk yang dihasilkan oleh depot air minum isi ulang dan PDAM yang relatif terjangkau, selain itu juga masih banyak masyarakat yang bertahan menggunakan sumur gali.

Menurut PERMENKES No. 492 tahun 2010 parameter mikrobiologi air minum yang wajib dipenuhi adalah batas minimum kandungan bakteri coliform dan Escherichia coly sebanyak 0 per $100 \mathrm{ml}$. Menurut Madigan (2012), apabila bakteri Escherichia coly ditemukan di dalam air, dapat menandakan adanya kontaminasi tinja dan air tersebut tidak aman untuk dikonsumsi. Air yang aman diminum adalah air bersih yang harus memenuhi persyaratan secara fisika, kimia, radioaktif dan mikrobiologi yang telah ditetapkan oleh pemerintah. Parameter wajib penentuan kualitas air minum secara mikrobiologi adalah total bakteri Coliform dan Escherichia coly. Salah satu syarat air bersih yang dapat dikonsumsi adalah tidak ditemukannya Coliform dan Escherichia coly dalam $100 \mathrm{ml}$ air.

Sebuah penelitian tentang kandungan bakteri Escherichia coly pada Depot Air Minum pernah dilakukan oleh Muzajjanah dkk tahun 2016 di Kecamatan Jagakarsa Jawa Barat. Dalam penelitian tersebut menunjukan bahwa dari 15 sempel Depot Air Minum terdeteksi mengandung bakteri Escherichia coly yaitu sebanyak 2 sampel.

Seorang mahasiswa dari Uneversitas Muhammadiyah Surakarta Alban Rhamadan tahun 2016 juga melakukan penelitian tentang kandungan Escherichia coly pada Sunber air minum Sumur Gali dan Sumur Pompa di terminal Tirtonadi Surakarta, hasil pemeriksaan laboratorium air sumur di Terminal Tirtonadi Surakarta terdapat 6 sampel air sumur gali yang mengandung bakteri Escherichia coly dengan jumlah yang bervariasi dari 1387,7 sampai dengan $>2,400$ bakteri Escherichia coli per $100 \mathrm{ml}$ air. Variasi jumlah Escherichia coly tersebut yang melebihi nilai maksimum air tanpa pipa yaitu $<50$ bakteri Escherichia coly per $100 \mathrm{ml}$. Sehingga semua sampel air sumur gali tersebut tidak memenuhi syarat sebagai sumber air bersih. Berbeda dengan sampel sumur air bor 5 sampel yang diperiksa menunjukan bahwa total Escherichia coly berkisar <10, sedangkan bakteri Escherichia coly 0 per $100 \mathrm{ml}$ air sehingga sesuai dengan syarat nilai maksimum air pipa dan air tersebut layak digunakan sebagai sumber air bersih.

Penelitian yang serupa juga dilakukan oleh Rani Aprisetiawati, Erly, Endrinaldi (FK Unuversitas Andalas) yang meneliti kandungan Escherichia coly pada Depot Air Minum di Kelurahan Lubuk Buaya Kota Padang, dari penelitian tersebut Empat dari dua belas sampel $(33,3 \%)$ tidak memenuhi persyaratan yang telah ditetapkan berdasarkan Peraturan Menteri Kesehatan No.492 tahun 2010. Dua belas sampel yang positif mengandung Coliform, terdapat satu sampel (8,3\%) yang mengandung bakteri Escherichia coly, sementara tiga sampel lain mengandung bakteri Coliform lain.

Sedangkan penelitian kandungan Escherichia coly pada PDAM Surakrta pernah dilakukan oleh Agus Prayitno tahun 2009, Hasil penelitian menunjukkan bahwa pada sampel 1 diperoleh indeks MPN 3:2:0 dan 1:0:0 pada uji penduga dan uji penegasan menunjukkan jumlah bakteri Coliform 93 sel 
dan 4 sel per $100 \mathrm{ml}$. Sampel 2 diperoleh indeks MPN 2:0:0 dan 1:0:0 pada pengujian pendugaan dan uji penegasan menunjukkan jumlah bakteri Coliform 9 sel dan 4 sel per $100 \mathrm{ml}$. Dapat disimpulkan bahwa sampel 1 dan 2 tidak layak untuk dikonsumsi berdasarkan uji bakteriologi menggunakan standart The Most Probable Number (MPN) dengan jumlah bakteri Coliform di atas 0 sel per $100 \mathrm{ml}$ sampel.

Penelitian mengenai Escherichia coly pada PDAM juga pernah dilakukan Finansita Harsari Putri tahun 2012, dalam penelitian ini di ambil titik sampel di beberapa titik dengan jarak yang berlainan. Angka Escherichia coly dari $0 \mathrm{~km}$ sampai dengan $8 \mathrm{~km}$ bernilai 0 , sedangkan Angka MPN coliform pada $0 \mathrm{~km}$ sebesar 33 per $100 \mathrm{ml}$ air, pada jarak $2 \mathrm{~km}$ angka MPN coliform 8 dan 2 per $100 \mathrm{ml}$ air, pada jarak $4 \mathrm{~km}$ angka MPN coliform 7 dan 2 per $100 \mathrm{ml}$ air, pada jarak $6 \mathrm{~km}$ angka MPN coliform 2 per $100 \mathrm{ml}$ air, dan pada jarak $8 \mathrm{~km}$ angka MPN coliform 0 per $100 \mathrm{ml}$ air.

Uji Escherichia coly pada Sumur Gali pernah dilakukan di Gorontalo tahun 2012 oleh Yuliana Polimengo, Berdasarkan analisis laboratorium untuk mengetahui kandungan bakteri Escherichia coly pada 9 sumur yang dijadikan sampel teridentifikasi bahwa sumur yang memenuhi syarat bakteriologis sebanyak 9 sumur atau sebesar $100 \%$.

Penelitian lain tentang kandungan Escherichia coly pada Sumur Gali juga pernah dilakukan tahun 2014 di Yogyakarta oleh Fadilah Ramadani dkk, dalam penelitian dilakukan penelitian pada hunian pemukiman padat dan hunian pemukiman kurang padat, hasilnya menunjukan jumlah escherichia coli pada air sumur gali di Dusun Blimbingsari yang merupakan kawasan permukiman dengan tingkat kepadatan tinggi tergolong tinggi, yaitu berkisar antara $0 \mathrm{CFU} / 100 \mathrm{ml}$ sampai $1.049 \mathrm{CFU} / 100 \mathrm{ml}$. Sementara itu jumlah Escherichia coly pada air sumur gali di Dusun Wonorejo yang merupakan kawasan permukiman dengan tingkat kepadatan rendah tergolong rendah, yaitu berkisar antara 1 CFU/100 ml sampai 6 CFU/100 ml. Kualitas air sumur gali di Dusun Wonorejo secara bakteriologis sudah memenuhi persyaratan, sehingga air tersebut aman secara kesehatan dan dapat dijadikan sebagai sumber air baku air minum.

Kelurahan Tanjung Raja Kecamatan Tanjung Raja Kabupaten Ogan Ilir adalah salah satu dari delapan Desa/Kelurahan yang ada di wilayah kerja Puskesmas Tanjung Raja Kecamatan Tanjung Raja yang Jumlah Penduduknya paling banyak dibandingkan dengan Desa/Kalurahan yang lain. Mobilitas masyarakat yang tinggi karena daerah perkotaan dengan penduduk padat dan berdekatan dengan pasar, tapi masih kental juga dengan penduduk asli dengan kebudayaannya, sehingga untuk pemenuhan kebutauhan air sehari hari sangat bervariasi sekali, yang menggunakan PDAM sebanyak 185 Kepala Keluarga, yang menggunakan Depot Air Minum sebanyak 240 Kepala Keluarga, yang menggunakan sumur gali sebanyak 809 Kepala Keluarga, yang menggunakan air sungai sebanyak 79 Kepala Keluarga, yang Menggunakan penampungan air hujan sebanyak 67 Kepala Keluarga, yang menggunakan sumur pompa tangan 53 Kepala Keluarga.

Sedangkan data diare 3 tahun terakhir untuk tahun 2016 di tingkat Provinsi Sumatera Selatan sebanyak 128.448 penderita, tingkat kabupaten Ogan Ilir sebanyak 8.653, untuk tingkat Puskesmas Tanjung Raja Sebanyak 324, dan tingkat Kelurahan Tanjung Raja Sebanyak 85. Tahun 2017 kasus diare di tingkat Provinsi Sumatera Selatan sebanyak 121.065 penderita, tingkat kabupaten Ogan Ilir sebanyak 8.071, untuk tingkat Puskesmas Tanjung Raja Sebanyak 609, dan tingkat Kelurahan Tanjung Raja Sebanyak 103. Sedangkan di tahun 2018 kasus diare Provinsi Sumatera Selatan sebanyak 101.184 penderita, tingkat kabupaten Ogan Ilir sebanyak 6.324, untuk tingkat Puskesmas Tanjung Raja Sebanyak 540, dan tingkat Kelurahan Tanjung Raja Sebanyak 98. Penyakit diare disebabkan karena adanya bakteri pada air yang dikonsumsi. (Juli Sumirat Slamet, 2010) Oleh 
karena itu peneliti tertarik untuk mengadakan penelitian tentang kandungan bakteri Escherichia coly yang ada di sumber air minum yang paling banyak digunakan masyarakat yaitu PDAM, Depot Air Minum, dan Sumur Gali di Kelurahan Tanjung Raja Kecamatan Tanjung Raja Kabupeten Ogan Ilir tahun 2019.

\section{METODE PENELITIAN \\ Jenis Penelitian}

Jenis penelitian yang dilakukan adalah penelitian analitik komparatif numerik, karena pada penelitia ini akan menghubungkan beberapa variabel kategorik terhadap satu variable numerik.

\section{Waktu dan Tempat Penelitian}

Lokasi penelitian di Kelurahan Tanjung Raja, Kecamatan Tanjung Raja, Tanjung Raja Kabupaten Ogan Ilir Provinsi Sumatera Selatan pada tanggal 1 Mei 2019 s/d 30 Juni 2019

\section{Subjek Penelitian}

Populasi dalam penelitian ini adalah sumber air minum PDAM 185 Titik, Depot Air Minum 8 Unit, Sumur Gali 809 Titik. Sampel yang akan diambil adalah Air Minum masyarakat yang bersumber dari PDAM, Depot Air Minum, dan Sumur Gali masing-masing adalah 5 titik sampel.

\section{Prosedur}

Pengumpulan data dilakukan dengan pengambilan langsung sampel ke lokasi penelitian dan memeriksa sampel tersebut di laboratorium. Untuk mengetahui kandungan bakteri Escherichia coly pada sumber air minum dilakukan uji MPN (Most Probable Number).

\section{Data, Intrumen, dan Teknik Pengumpulan Data}

Pengumpulan data dilakukan dengan pengambilan langsung sampel ke lokasi penelitian dan memeriksa sampel tersebut di laboratorium. Untuk mengetahui kandungan bakteri Escherichia coly pada sumber air minum dilakukan uji MPN (Most Probable Number). Alat dan Bahan Pengumpul Data

a. Alat pengumpul data
a) Inkubator $37^{\circ} \mathrm{C}$
b) Autoclave untuk sterilisasi
c) Rak tabung reaksi
d) Tabung reaksi
e) Labu Erlemeyer
f) Pipa Steril : $1 \mathrm{cc}$ dan $10 \mathrm{cc}$
g) Kawatohse
h) Tabung durham (Volume tabung $\pm 2 \mathrm{ml}) 15$ tabung untuk sampel.
i) Kapas
j) Lampu Bunsen
k) Label
1) Bahan pengumpul data
m) Gram Buffer phosphate $\mathrm{pH} 7,2$
n) Lactosa Broth
o) BGLB
p) Alkohol 99\%

b. Prosedur pengambilan sampel

1. Sampel PDAM
a. Siapkan botol steril, lampu Bunsen, label
b. Ambil sampel yang akan diperiksa
c. Siapkan botol steril, isi botol sampai $3 / 4$ botol, tutup kembali botol dengan kapas penutup botol.
d. Beri label

2. Sampel Depot Air Minum
a. Siapkan botol steril, lampu Bunsen, label
b. Panaskan bibir kran dengan menggunakan lampu bunses
c. Hidupkan air kran selama kurang lebih 1 menit dengan membiarkan air keluara
d. Panaskan kembali bibirkran dengan menggunakan lampu Bunsen
e. Siapkan botol steril, isi botol sampai $3 / 4$ botol, tutup kembali botol dengan kapas penutup botol.
f. Beri label

3. Sampel Sumur Gali 
b. Siapkan sampel yang akan diperiksa

c. Isi botol sampai dengan $3 / 4$ botol.

d. Tutup kembali botol dengan menggunakan kapas

e. Beri label

4. Prosedur pemeriksaan sampel

1. Tes Penduga (Persumtive test)

Dalam tahap Tes Penduga ini bahan yang biasa digunakan adalah Lactose Broth. Cara pemeriksaan yaitu dengan mempersiapkan 9 buah tabung reaksi masing-masing media LB yang didalamnya terdapat tabung durham. Air ditanam pada 3 tabung, yang mana masing-masing berisi 3 tabung: $10 \mathrm{ml}$, 3 tabung: 1ml, 3 tabung: $0,1 \mathrm{ml}$ dapat dituliskan standart portion; 3 x 10ml, 3 $\mathrm{x} 1 \mathrm{ml}, 3$ x $0,1 \mathrm{ml}$.

Seluruh tabung diinkubasi selama 24-48 jam pada suhu 37oC.Setelah diinkubasi dilihat hasilnya, apabila terdapat gas dalam tabung durham hasilnya positif. Namun, apabila tidak ada gas didapatkan hasil negatif.Kemudian dicatat berapa banyak tabung yang terisi oleh gas. Kemudian dapat diteruskan dengan Tes Penguat.

2. Tes Penguat (Confirmed test)

Dalam tahap Tes Penguatan atau konfirmasi yang digunakan adalah Brillian Green Lactose Broth (BGLB). Cara pemeriksaan dilakukan pemindahan sebanyak 1-2 os ke dalam tabung penguat yang telah berisi $10 \mathrm{ml}$ BGLB 2\%.Semua tabung diinkubasi selama 24 jam padasuhu $37 \mathrm{o}$ C. Pembacaan dilakukan setelah 24 jam dengan melihat adanya gas pada tabung durham yang memperkuat adanya bakteri Escherichia coli. Pembacaan hasil angka bakteri Escherichia coli didapatkan dari tabung yang berisi gas pada tabung durham kemudian dicocokan pada tabel MPN (Bambang, 2014).

3. Uji Pelengkap (Complete test)
Uji Pelengkap (Complete test) Hasil yang positif mengandung gas pada tes penegasan dilanjutkan menggunakan tes pelengkap yaitu dengan menggoreskan ose ke permukaan Endo agar dari tabungtabung yang positif, dengan dugaan terdapat koloni berwarna kehitaman seperti kilat logam

\section{Teknik Analisis Data}

\section{Analisis Univariat}

Analisis univariat dilakukan untuk mengetahui distribusi frekuensi dan beda rata-rata kandungan bakteri Escherichia coly pada sumber airminum untuk data kategorik, dan nilai Mean, Median, Standar Deviasi (SD), Standar Eror (SE), Nilai Minimal (MIN), Nilai Maksimal (Max), dan Jumlah sampel untuk variable data numerik.

\section{Analisis Bivariat}

Analisis bivariat digunakan untuk mengetahui apakah ada beda rata-rata kandungan bakteri Escherichia coly pada sumber air minum PDAM, Depot Air Minum, dan Sumur Gali di Kelurahan Tanjung Raja Kecamatan Tanjungg Raja Kabupaten Ogan Ilir tahun 2019. Penelitian ini menggunakan uji statistik Anova karena terdapat tiga variable independen.

Batas kemaknaan ( $\alpha)$ yang digunakan dalam penelitian ini adalah 5\% $(0,05)$. Dasar pengambilan keputusan statistik dilakukan dengan membandingkan $p$ value dengan nilai $\alpha$ $(0,05)$, dengan ketentuan (Hastono, 2001).

\section{HASIL PENELITIAN DAN PEMBAHASAN}

Hasil Pemeriksaan Kandungan bakteri Eschericia Coly diperoleh dari pengujian laboratorium uji MPN ( Most Probable Number) oleh Balai Teknik Kesehatan Lingkungan Kelas 1 (BTKL) Palembang dengan menggunakan parameter 
persyaratan kualitas air minum berdasarkan Permenkes RI No. 492/Menkes/Per/IV/2010. Hasil pemeriksaan adalah sebagai berikut :

1. Analisis Univariat

Analisis univariat dilakukan untuk mengetahui distribusi frekuensi dan beda rata-rata kandungan bakteri Eschericia Coly pada air minum PDAM, Depot Air Minum, dan Sumur Gali, serta nilai standar deviasi, Standar Eror, Nilai maksimum, Nilai minimum dan jumlah sampel pada data nomerik yang ditunjukan pada tebel berikut :

Tabel Gambaran kandungan bakteri Eschericia Coly Pada Air Minum Sumber PDAM, Depot Air Minum, dan Sumur Gali

\begin{tabular}{|c|c|c|c|c|c|c|}
\hline No & $\begin{array}{c}\text { Jenis } \\
\text { Sumber } \\
\text { Air } \\
\text { Minum }\end{array}$ & Mean & $\begin{array}{c}\text { Std } \\
\text { Deviasi }\end{array}$ & $\begin{array}{l}\text { Std } \\
\text { Eror }\end{array}$ & $\begin{array}{c}\text { Nilai } \\
\text { Minimal }\end{array}$ & $\begin{array}{c}\text { Nilai } \\
\text { maksimal }\end{array}$ \\
\hline 1 & $\begin{array}{l}\text { PDAM } \\
\text { Depot }\end{array}$ & 3,80 & 2,168 & 0,970 & 1 & 6 \\
\hline 2 & $\begin{array}{l}\text { Air } \\
\text { Minum }\end{array}$ & 0,80 & 0,837 & 0,374 & 0 & 2 \\
\hline 3 & $\begin{array}{l}\text { Sumur } \\
\text { Gali }\end{array}$ & 2,20 & 1,483 & 0,663 & 0 & 4 \\
\hline & Total & 2,27 & 1,944 & 0,502 & 0 & 6 \\
\hline
\end{tabular}

Dari tebel distribusi frekuensi diatas dapat dilihat bawa rata-rata kandungan Eschericia Coly pada PDAM adalah 3,80, dengan standar Deviasi 2,186, Standar eror 0,970, minimum 1, dan maksimum 6 .

Sedangkan rata-rata kandungan Eschericia Coly pada Depot Air Minum adalah 0,80, dengan standar Deviasi 0,837, Standar eror 0,375, minimum 0, dan maksimum 2. Dan rata-rata kandungan Eschericia Coly pada Sumur Gali adalah 2,20, dengan standar Deviasi 1,483, Standar eror 0,663, minimum 0 , dan maksimum 4. Dengan demikian, secara deskriptif dapat disimpulkan bahwa rata-rata kandungan bakteri Eschericia Coly tertinggi adalah pada Sumber Air Minum PDAM yaitu sebesar 3,80.
2. Analisis Bivariat

Analisis dilakukan dengan uji anova untuk mecari apakah ada beda rata-rata kandungan bakteri Eschericia Coly pada seumber air minum PDAM, Depot Air Minum, dan Sumur Gali di Kelurahan Tanjung Raja Kecamatan Tanjung Raja Kabupaten Ogan Ilir tahun 2019. Hasil uji hipotesis ditunjukan pada tabel berikut:

Tabel Perbandingan rata-rata kandungan bakteri Eschericia Coly Pada Air Minum Sumber PDAM, Depot Air Minum, dan Sumur Gali

\begin{tabular}{|c|c|c|c|}
\hline No & $\begin{array}{c}\text { Jenis Sumber } \\
\text { Air Minum }\end{array}$ & $\begin{array}{c}\text { Mean } \\
\text { Difference }\end{array}$ & $\begin{array}{c}\text { Sig } \\
(p \text { value })\end{array}$ \\
\hline 1 & $\begin{array}{l}\text { PDAM } \\
\text { dengan Depot } \\
\text { Air Minum }\end{array}$ & 3,00 & 0,029 \\
\hline 2 & $\begin{array}{l}\text { PDAM } \\
\text { dengan Sumur } \\
\text { Gali }\end{array}$ & 1,600 & 0,287 \\
\hline 3 & $\begin{array}{l}\text { Sumur Gali } \\
\text { dengan Depot } \\
\text { Air Minum }\end{array}$ & $-1,400$ & 0,376 \\
\hline
\end{tabular}

Pada tebel diatas terlihat bahawa $p$ value kandungan bakteri Eschericia Coly pada PDAM dan Depot Air Minum adalah $0,029 \leq 0,05$. Maka dapat disimpulkan bahwa perbedaan rata-rata kandungan bakteri Eschericia Coly pada PDAM dan Depot Air Minum adalah tidak sama. Sehingga perbedaan rata-rata kandungan bakteri Eschericia Coly pada PDAM dan Depot Air Minum tersebut sangat signifikan.

Berbeda juga dengan nilai $p$ value kandungan bakteri Eschericia Coly pada PDAM dan Sumur Gali yaitu 0,287 $\geq 0,05$. Maka dapat disimpulkan bahwa perbedaan rata-rata kandungan bakteri Eschericia Coly pada PDAM dan Sumur Gali adalah sama. Sehingga perbedaan rata-rata kandungan bakteri Eschericia Coly pada PDAM dan Sumur Gali tersebut tidaklah signifikan. 


\section{KESIMPULAN}

Dari hasil penelitian diperoleh nilai $p$ value hasil penelitian yaitu $0,029 \leq$ Alpha

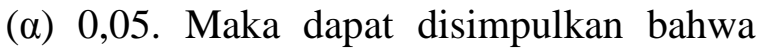
rata-rata kandungan bakteri Eschericia Coly pada Air Minum Sumber PDAM dan Depot Air Minum di Kelurahan Tanjung Raja Kecamatan Tanjung Raja Kabupaten Ogan Ilir Tahun 2019 berbeda secara signifikan.

\section{SARAN}

Sebaiknya dilakukan pemeriksaan rutin terhadap air minum yang dikonsumsi masyarakat, selain itu juga perlu melakukan penyuluhan kepada masyarakat tentang pentingnya menggunakan air yang sehat dan memenuhi syarat kesehatan.

\section{DAFTAR PUSTAKA}

Arikunto, Suharsimi. 2010. Prosedur penelitian suatu pendekatan praktek. Jakarta : Rineka Cipta

Dahlan, M.Sopiyudin. 2010. Langkahlangkah pembuatan proposal penelitian bidang kedokteran dan kesehatan. Jakarta : Rstat Consulting.

Dirjen P2PL Kemenkes RI. 2011. Panduan Sistem Surveilans Air Minum dan Sanitasi. Jakarta : Kemenkes RI.

Direjen P2PL Kemenkes RI. 2014. Petunjuk Teknis perlindungan sumber air baku air munim. Jakarta : Kemenkes RI.

Dirjen P2PL Kemenkes RI. 1996. Dasar penetapan dampak kualitas air terhadap kesehatan masyarakat. Jakarta : Kemenkes RI.

Huwaida, Rizka N. 2014. Faktor-faktor yang mempengaruhi Jumlah E. Coly Air bersih pada penderita diare di Kelurahan Paku Jaya Kecamatan Serpong Utara Kota Tangerang
Selatan. Jakarta : UIN Syarif Hidayatulloh

Menteri Kesehatan RI. Permenkes RI No. 492/Menkes/Per/IV/2010 tentang persyaratan kualitas airminum Jakarta : Kemenkes RI. Presiden RI. 2015.

Peraturan Pemerintah RI No. 122 tahun 2015 tentang system penyediaan air minum. Jakarta : Lembar Negara.

Ramadhan, Alban. 2016. Perbandingan bakteriologi Escherichia Coly pada sumber air minum sumur gali dengan sumbe air minum sumur Bor di terminal Tirtonadi Surakarta Surakarta : Universitas Muhammadiyah Surakarta.

Soemirat, Juli S. 2007. Kesehatan Lingkungan. Yogyakarta : Gajah Mada University Press.

Sumantri, Arif. 2011. Metodologi Penelitian Kesehatan. Jakarta: Kencana Prenada Media Grup

Waluyo, L. 2008. Teknik dan Metode Dasar dalam Mikrobiologi. Malang: Universitas Muhammadiyah Malang Press.

Zamhari, Muhammad. Pencemaran Lingkungan, Mitra Utama, Pondok Melati Bekasi Jawa Barat, 2011. 